Зинанте, 1975. - $120 \mathrm{c.}$

2. Кабанов А.В. Проблемы охранения генофонда декоративных растений на примере коллекции рода Astilbe Buch-Ham в отделе декоративных растений ГБС РАН. // Цветоводство: традиции и современность: матер. VI Межд. науч. конф. / Отв. ред. А.С. Демидов. - Белгород: ИД «Белгород» НИУ «БелГУ», 2013 г. - С. 271-274.

3. Верещагина И.В. Культура цветочных растений в Алтайском крае. - Барнаул: Алтайское книж. изд-во, 1968. - 143 с.

4. Методика государственного сортоиспытания сельскохозяйственных культур: декоративные культуры. М.: Изд-во Мин-ва сел. хоз-ва РСФСР, 1968. Вып. 6. - С. $56-89$.

5. Куранда Ю.В. Возможность семенного размножения и первичная оценка сеянцев Astilbe Buch-Ham. от свободного опыления сортов. // Проблемы промышленной ботаники индустриально развитых регионов. / Отв. ред. Куприянов А.Н. Кемерово: ФИЦ УУХ СО РАН, 2018 г. - С. 72-74.

DOI 10.18699/GPB2020-46

\title{
Генетическое разнообразие и биохимическая ценность культур Raphanus L. коллекции ВИР
}

Курина А.Б. м.н.с., Соловьева А.Е. к.б.н., с.н.с., Артемьева А.М. к.с.-х.н., в.н.с. ФГБНУ «Федеральный исследовательский центр Всероссийский институт генетических ресурсов растений им. Н.И. Вавилова (ВИР)», г. Санкт-Петербург, Россия.

e-mail: nastya_n11@mail.ru

Изучение генофонда культур Raphanus L. имеет большое значение в вопросах оценки исходного материала и выявления источников хозяйственно-ценных признаков для селекции. Это связано с недостаточной изученностью физиологической реакции образцов различных сортотипов на условия выращиввания, биохимических особенностей, пределов изменчивости признаков селекционного интереса, экологической пластичности, адаптационных возможностей, устойчивости к абиотическим и биотическим стрессам. Изучение разнообразия культур Raphanus L. коллекции ВИР позволит всесторонне оценить коллекцию, описать новые формы и сортотипь, выявить биологические закономерности формирования фотосинтетического аппарата, урожая, устойчивости к биотическим и абиотическим стрессорам. В результате исследований оценен в контрастных условиях выращивания диапазон проявления признаков интереса, их стабильность/лабильность, определень эколого-географические группь и сортотипь, которые содержат источники ценных признаков, выделены образцы с высоким адаптационным потенциалом. 
Ключевые слова: Raphanus L., генетическое разнообразие, изменчивость, признаки.

\section{Genetic diversity and biochemical value of VIR collections of the Raphanus L.}

A.B. Kurina, A.E. Soloveva, A.M. Artemyeva

Federal Research Centre N.I. Vavilov Institute of Plant Genetic Resources (VIR), Russia, Saint-Petersburg

e-mail:nastya_n11@mail.ru

The study of the diversity of plants of the genus Raphanus L. is of great importance in assessing the source material and identifying sources of economically valuable traits for breeding. This is connect to insufficient study of the physiological response of samples of various types to growing conditions, biochemical characteristics, the limits of variability of traits of breeding interest, ecological sustainability, adaptive ability and resistance to abiotic and biotic stresses. The study of the diversity of VIR collection of plants of the genus Raphanus L. will make it possible to comprehensively evaluate the collection, describe new forms and varieties, and find the biological patterns of photosynthetic apparatus formation, productivity, and resistance to biotic and abiotic stressors. As the results of our study, the range of manifestation and stability of traits of interest during grows in contrast growing conditions was detected. Several ecologo-geographical groups, types of varieties and samples from the small radish collection, with high adaptive potential, were identified. They can be used like the sources of valuable traits for the future breeding programs.

Key words: Raphanus L., genetic diversity, variability, traits.

Род Raphanus L. включает в себя 10 видов, из которых возделываются только четыре: R. sativus L. (редис, редька), R. landra Mor. (редька листовая), $R$. indicus Sinsk. (редька индийская), $R$. caudatus L.(редька змеевидная) [1].

Редька и редис (Raphanus sativus L.) являются корнеплодными растениями, выращиваемыми и потребляемыми во всем мире. В настоящее время различают три крупные изолированные географические группы редьки и редиса - европейскую, китайскую и японскую. Каждая группа имеет разновидности и сортотипы, различающиеся по комплексу морфологических, фенологических, биохимических и хозяйственно-ценных признаков.

Редька индийская ( $R$. indicus Sinsk.) и змеевидная ( $R$. caudatus L.) являются малораспространенными видами и редко используются в качестве источника пищи. Данные культуры популярны в странах Южной Азии. Редька индийская и змеевидная не образуют съедобного корнеплода, в пищу употребляются стручки [1].

Редька листовая (R. landra Mor.) является дикорастущей и распространена в странах Западного Средиземноморья. Растения не формируют съе- 
добного корня, но формируют много листовой массы, которую можно употреблять в пищу [1].

В целом культуры Raphanus L. содержат углеводы, сахара, пищевые волокна, различные водорастворимые витамины $\left(\mathrm{B}_{1}, \mathrm{~B}_{2}, \mathrm{~B}_{3}, \mathrm{~B}_{5}, \mathrm{~B}_{6}, \mathrm{~B}_{9}\right.$ и $\left.\mathrm{C}\right)$ и минералы (кальций, железо, магний, марганец, цинк, калий и фосфор) [2]. Кроме того, они содержат уникальные биоактивные соединения, которые недавно были признаны потенциально полезными для здоровья человека [35]. Фармакологическая активность культур Raphanus L. является результатом многих важных химических компонентов, в том числе флавоноидов, антоцианов, фенольных соединений, гликозидов, витаминов, горчичных и эфирных масел [6-8]. Эффективное использование культур Raphanus L. отмечено при сердечно-сосудистых заболеваниях, диабете, раке и других желудочных заболеваниях. Сообщалось также, что они являются очень эффективным гепатозащитным средством. Было установлено, что различные части, такие как листья, корни, семена, обладают антиоксидантными свойствами [9-15].

Таким образом, изучению генофонда Raphanus L. и созданию исходного материала по основным направлениям селекции культур: разные группы спелости, масса, форма и окраска корнеплода, оптимальное соотношение массы корнеплода к общей массе растения (выше 60 \%), устойчивость к раннему стеблеванию, неопушенный цельный лист, компактная листовая розетка, высокие вкусовые качества и ценный биохимический состав, - необходимо отводить большую роль, учитывая, что вопросы оценки исходного материала и выявления источников хозяйственно-ценных признаков для селекции данных культур разработаны недостаточно. Недостаточно изучена физиологическая реакция образцов различных сортотипов на условия выращивания, биохимические особенности, пределы изменчивости признаков селекционного интереса, экологическая пластичность, адаптационные возможности, устойчивость к абиотическим и биотическим стрессам.

Мировая коллекция ВИР культур Raphanus L. включает 2810 образцов, из которых: редиса - 1600, редьки - 1200, других видов - 10 образцов, поступивших из 75 стран мира.

В настоящее время в ВИР активно ведется всестороннее исследование коллекции Raphanus L. За последние годы изучено 155 образцов редиса, 155 - редьки, 5 - редьки змеевидной $(R$. caudatus L.) и 3 - редьки листовой $(R$. landra Mor.) различного эколого-географического происхождения и ботанической принадлежности по морфологическим, фенологическим, биохимическим и хозяйственно ценным признакам в условиях открытого и защищенного (зимняя остекленная и весенняя поликарбонатная теплица) грунта и в условиях интенсивной светокультуры.

В результате выявлено, что пределы изменчивости морфологических признаков, а также признаков продуктивности, скороспелости у культур 
Raphanus L. достаточно велики (таблица).

Таблица - Изменчивость количественных признаков листового аппарата и корнеплода редьки и редиса в среднем за 2016-2018 гг.

\begin{tabular}{|c|c|c|c|c|c|c|c|c|}
\hline \multirow{2}{*}{ Признак } & \multicolumn{4}{|c|}{ Редька } & \multicolumn{5}{|c|}{ Редис } \\
\cline { 2 - 10 } & $\mathrm{X}_{\mathrm{cp}}$ & $\mathrm{X}_{\min }$ & $\mathrm{X}_{\max }$ & $\begin{array}{c}\text { Cv, } \\
\%\end{array}$ & $\mathrm{X}_{\mathrm{cp}}$ & $\mathrm{X}_{\min }$ & $\mathrm{X}_{\max }$ & $\begin{array}{c}\mathrm{Cv} \\
\%\end{array}$ \\
\hline $\begin{array}{c}\text { Вегетационный период, } \\
\text { дни }\end{array}$ & 50,82 & 32,00 & 88,00 & 27,44 & 27,3 & 18,0 & 51,0 & 22,7 \\
\hline Высота розетки, см & 25,38 & 13,30 & 42,60 & 21,94 & 20,07 & 10,40 & 33,60 & 18,89 \\
\hline Диаметр розетки, см & 29,07 & 15,00 & 44,80 & 14,63 & 16,25 & 9,38 & 25,18 & 17,04 \\
\hline Длина листа, см & 14,56 & 7,50 & 25,70 & 19,99 & 11,14 & 6,29 & 18,40 & 17,19 \\
\hline Ширина листа, см & 9,65 & 5,50 & 13,30 & 14,07 & 7,21 & 3,86 & 12,40 & 18,66 \\
\hline $\begin{array}{c}\text { Площадь листовой по- } \\
\text { верхности, см }\end{array}$ & 1336,99 & 344,70 & 3999,14 & 41,65 & 431,19 & 135,43 & 1140,06 & 32,93 \\
\hline Длина корнеплода, см & 14,17 & 3,50 & 37,10 & 45,08 & 4,53 & 1,67 & 13,50 & 44,67 \\
\hline Диаметр корнеплода, см & 5,75 & 2,69 & 10,14 & 21,88 & 2,55 & 0,86 & 4,40 & 19,29 \\
\hline Индекс корнеплода & 2,69 & 0,73 & 8,56 & 58,96 & 1,94 & 0,66 & 8,00 & 60,72 \\
\hline Масса растения, г & 416,37 & 53,60 & 1050,00 & 46,34 & 34,07 & 11,42 & 75,70 & 34,71 \\
\hline Масса корнеплода, г & 271,18 & 35,80 & 723,00 & 51,13 & 18,02 & 6,25 & 41,50 & 33,34 \\
\hline Доля корнеплода, \% & 66,39 & 13,19 & 92,78 & 21,35 & 53,83 & 25,00 & 89,13 & 14,59 \\
\hline
\end{tabular}

В результате биохимических исследований было идентифицировано 134 показателя химического состава, из них: органических кислот - 23, сахаров - 15, фенольных соединений - 10, свободных аминокислот - 26 , жирных кислот -17 , спиртов - 14 и ряд вторичных метаболитов - 29. Размах вариации содержания каждого из изученных биохимических соединений был очень велик.

Изучение видового и сортового разнообразия Raphanus L. по биохимическим признакам качества позволило выявить пределы изменчивости по содержанию массы сухих веществ, сахаров, аскорбиновой кислоты, органических кислот, фенольных соединений, свободных аминокислот, жирных кислот и спиртов. Например, у редиса амплитуда изменчивости составляла: массы сухих веществ - от 4 до $8 \%$, аскорбиновой кислоты - от 19 до 44 мг $/ 100$ г, сахаров от $0,16 \%$ до 5,45\%, суммы органических кислот от $0,18 \%$ до 1,72 \%, фенольных соединений - от 7 до 793 мг/100 г, свободных аминокислот - от 9 до 516 мг/100 г, свободных жирных кислот - от 8 до 669 мг/100 г, спиртов - от 14 до 4768 мг/100 г. У редьки масса сухих веществ варьировала от 5 до $13 \%$, аскорбиновой кислоты - от 39 до 85 мг/100 г, сахаров от $0,1 \%$ до $1,93 \%$, суммы органических кислот от $0,01 \%$ до $0,74 \%$, фенольных соединений от 0,6 до 103 мг/100 г, свободных аминокислот от 3 до 102 мг/100 г, свободных жирных кислот от 2 до 54 мг/100 г, спиртов от 1 до 763 мг/100 г. 
У редиса выделены источники устойчивости к раннему стеблеванию в условиях длинного дня, пониженных и повышенных температур, исследована стабильность и пластичность образцов различных сортотипов и выделен материал с высоким адаптационным потенциалом среди образцов сортотипов Розово-красный округлый и Красный округлый. Выделены источники устойчивости редьки к раннему стеблеванию при весеннем посеве, образцы с высокой продуктивностью, высоким содержанием аскорбиновой кислоты и сахаров, слабо поражающиеся личинками капустной мухи.

В результате исследований оценен в контрастных условиях выращивания диапазон проявления признаков интереса, их стабильность/лабильность, определены эколого-географические группы и сортотипы, которые содержат источники ценных признаков, выделены образцы с высоким адаптационным потенциалом.

Благодарности: Работа выполнена в рамках выполнения государственного задания № 0662-2019-003 «Генетические ресурсы овощных и бахчевых культур мировой коллекции ВИР: эффективные пути расширения разнообразия, раскрытия закономерностей наследственной изменчивости, использования адаптивного потенциала».

\section{Список литературы}

1. Шебалина М.А., Сазонова Л.В. Корнеплодные растения // Культурная флора СССР. Т. 18. - Л.: Агропромиздат, ЛО, 1985. - С. 156-324.

2. Khattak K.F. Nutrient composition, phenolic content and free radical scavenging activity of some uncommon vegetables of Pakistan. - Pak. J. Pharm. Sci. 2011, 24, 277-283.

3. Malik M.S., Riley M.B., Norsworthy J.K., Bridges W. Jr. Variation of glucosinolates in wild radish (Raphanus raphanistrum) accessions. - J. Agric. Food Chem. 2010, 58, 11626-11632.

4. Ishida M., Kakizaki T., Morimitsu Y., Ohara T., Hatakeyama K., Yoshiaki H., Kohori J., Nishio T. Novel glucosinolate composition lacking 4-methylthio-3-butenyl glucosinolate in japanese white radish (Raphanus sativus L.). - Theor. Appl. Genet. 2015, 128, 2037-2046.

5. Baenas N., Piegholdt S., Schloesser A., Moreno D.A., Garcia-Viguera C., Rimbach G., Wagner A.E. Metabolic activity of radish sprouts derived isothiocyanates in drosophila melanogaster. - Int. J. Mol. Sci. 2016, 17, 251.

6. Brunetti C., Di Ferdinando, M. Fini, A. Pollastri, S. Tattini Flavonoids as antioxidants and developmental regulators: relative significance in plants and humans. - Int. J. Mol. Sci 14, 2013, 3540-55.

7. Nakabayashi R. et al. Enhancement of oxidative and drought tolerance in Arabidopsis by overaccumulation of antioxidant flavonoids. - Plant J 77, 2014, 367-79.

8. Gutierrez E. et al. Transcriptomics, Targeted Metabolomics and Gene Expression of Blackberry Leaves and Fruits Indicate Flavonoid Metabolic Flux from Leaf to Red Fruit. - Front. Plant Sci 8, 2017, 472.

9. Lugasi A., Dworschak E., Blazovics A., Kery A. Antioxidant and free radical scavenging properties of squeezed juice from black radish (Raphanus sativus L. var 
niger) root. - Phytotherapy research. 12 (7), 1998, 502-506.

10. Papi A., Orlandi M., Bartolini G., Barillari J., Iori R., Paolini M., Ferroni F., Grazia Fumo M., Pedulli G.F., Valgimigli L. Cytotoxic and antioxidant activity of 4methylthio-3-butenyl isothiocyanate from Raphanus sativus L. (Kaiware Daikon) sprouts. - Journal of agricultural and food chemistry. 56 (3), 2008, 875-883.

11. Barillari J., Cervellati R., Costa S., Guerra M.C., Speroni E., Utan A., Iori R. Antioxidant and choleretic properties of Raphanus sativus L. sprout (Kaiware Daikon) extract. - Journal of agricultural and food chemistry. 54 (26), 2006, 9773-9778.

12. Beevi S. S., Narasu M.L., Gowda B.B. Polyphenolics profile, antioxidant and radical scavenging activity of leaves and stem of Raphanus sativus L. - Plant foods for human nutrition. 65 (1), 2010, 8-17.

13. Takaya Y., Kondo Y., Furukawa T., Niwa, M. Antioxidant constituents of radish sprout (kaiware daikon), Raphanus sativus L. - Journal of agricultural and food chemistry. 51 (27), 2003, 8061-8066.

14. Vanitha Reddy P., Desai S., Ahmed F., Urooj A. Antioxidant properties and stability of Raphanus sativus extracts. - Journal of Pharmacy Research. 3 (3, Cop), 2010, 658-661.

15. Wu S., Gao Q., Zhao P., Gao Y., Xi Y., Wang X., Liang Y., Shi H., Ma, Y. Sulforaphane produces antidepressant-and anxiolytic-like effects in adult mice. $-\mathrm{Be}$ havioural brain research. 301, 2016, 55-62.

DOI 10.18699/GPB2020-47

\section{Современное состояние генофонда рода седум (Sedum L.) в НИИСС имени М.А. Лисавенко}

Ларина О.В., к.с.-х.н., н.с.

Федеральный Алтайский научный иентр агробиотехнологий, Барнаул, Россия e-mail:olia.sadovod@yandex.ru

В НИИСС имени М.А. Лисавенко коллекция рода Sedum L. включает 14 видов, 2 формы и 7 сортов. Представлены сведения о сроках, продолжительности иветения 23 объектов исследования в условиях лесостепной зоны Алтайского края. Перспективные образиы с высокими показателями декоративности и устойчивости рекомендованы для использования в озеленении региона.

Ключевые слова: интродукиия, седум, толстянковые, декоративность, перспективность, адаптивность.

\section{Current state of the gene pool Sedum L.} at the NIISS named after M.A. Lisavenko

Larina O.V.

Federal Altai Scientific Centre of Agro-BioTechnologies, Barnaul, Russia.

At the NIISS named after M.A. Lisavenko collection of the genus Sedum L. 